
Revue canadienne de chimie

Selective access to p-dialkyl-carbo-benzenes from a [6]pericyclynedione: the n-butyl nucleophile model for a metal switch study

\begin{tabular}{|r|l|}
\hline Journal: & Canadian Journal of Chemistry \\
\hline Manuscript ID & Cjc-2016-0629.R1 \\
\hline Manuscript Type: & Article \\
\hline Date Submitted by the Author: & 09-Jan-2017 \\
\hline Complete List of Authors: & $\begin{array}{l}\text { Zhu, Chongwei; University of Toulouse 3 - Paul Sabatier, Laboratoire de } \\
\text { Chimie de Coordination du CNRS } \\
\text { Duhayon, Carine; CNRS, Laboratoire de Chimie de Coordination, UPR 8241 } \\
\text { Saquet, Alix; CNRS, Laboratoire de Chimie de Coordination, UPR 8241 } \\
\text { Maraval, Valérie; CNRS, Laboratoire de Chimie de Coordination, UPR 8241 } \\
\text { Chauvin, Remi; Universite Toulouse III Paul Sabatier, Laboratoire de } \\
\text { Chimie de Coordination du CNRS, UPR 8241 }\end{array}$ \\
\hline Keyword: & Alkylcerium, Alkyne, Aromatics, Carbo-benzene, Carbo-mer \\
\hline \multicolumn{2}{|c}{} \\
\hline
\end{tabular}




\title{
Selective access to $p$-dialkyl-carbo-benzenes from a [6]pericyclynedione: the $n$-butyl nucleophile model for a metal switch study ${ }^{\dagger}$
}

\author{
Chongwei Zhu, ${ }^{a, b}$ Carine Duhayon, ${ }^{a, b}$ Alix Saquet, ${ }^{a, b}$ Valérie Maraval, ${ }^{a, b^{*}}$ Remi Chauvin ${ }^{a, b^{*}}$ \\ ${ }^{a}$ CNRS, LCC (Laboratoire de Chimie de Coordination), 205 route de Narbonne, BP 44099, 31077 Toulouse \\ Cedex 4, France \\ ${ }^{b}$ Université de Toulouse, UPS, ICT-FR 2599, 118 route de Narbonne, 31062 Toulouse Cedex 9, France
}

E-mail: valerie.maraval@lcc-toulouse.fr, chauvin@lcc-toulouse.fr

\begin{abstract}
The synthesis, spectroscopic properties, comparative electrochemical behavior in $\mathrm{CHCl}_{3}$ vs $\mathrm{CH}_{2} \mathrm{Cl}_{2}$, and X-ray crystal structure of $p$-di- $n$-butyl-tetraphenyl-carbo-benzene are described. The selectivity of preparation of the ultimate [6]pericyclynediol precursor has been examined by comparing the reactivity of the [6]pericyclynedione substrate with four $n$-Bu-MX nucleophiles involving more or less halogenated metal centers $\mathrm{MX}_{\mathrm{n}}(0 \leq \mathrm{n} \leq 2)$ : $\mathrm{Li}, \mathrm{MgBr}$, $\mathrm{MgCl}, \mathrm{CeCl}_{2} / \mathrm{LiCl}$. The cerium reagent is found to be the most efficient, giving $c a$ twice the yield given by Grignard reagents in the target diadduct (90\% vs 51-53\%). The dibutyl-carbobenzene product happens to be soluble in both $\mathrm{CHCl}_{3}$ and $\mathrm{CH}_{2} \mathrm{Cl}_{2}$, cyclic voltammograms of either solutions exhibiting almost identical peak potentials, with reduced reversibility of the redox processes in $\mathrm{CHCl}_{3}$.
\end{abstract}

Key-words. Alkylcerium - Alkyne - Aromatics - Carbo-benzene - Carbo-mer

${ }^{\dagger}$ Dedicated to Prof. Reginald H. Mitchell on the occasion of its retirement and prospect of a long remaining life in inspiring the design and study of novel aromatic compounds. 


\section{Introduction}

Among $\pi$-conjugated carbon allotropes and beyond the foremost graphene type, graphynic materials, composed of both $\mathrm{sp}^{2}-\mathrm{C}$ and $\mathrm{sp}-\mathrm{C}$ atoms, have been considered at the theoretical level, ${ }^{1}$ but more sparingly studied experimentally. Nevertheless, several molecular fragments of $\gamma$-graphyne, ${ }^{2} \gamma$-graphdiyne, ${ }^{3}$ and even $\alpha$-graphyne, ${ }^{4}$ have been described. A key issue in the synthesis and study of such carbon-rich compounds is their limiting solubility, approaching that of graphite upon increase of the size of the carbon core within a $\mathrm{C}-\mathrm{H}$ bond periphery. As a recourse, peripheral decoration by lipophilic groups is currently envisaged. This can be illustrated by the recent report of a ring carbo-mer of naphthalene, ${ }^{5}$ eight $p$ pentylphenyl substituents of the $\mathrm{C}_{32}$ core having allowed full characterization of this first example of fused polycyclic $\alpha$-graphyne fragment, in or from solutions in $\mathrm{CHCl}_{3}{ }^{4}$ The solubilizing effect of the p-pentylphenyl groups appeared however limited, even on the smaller carbo-benzene congener $\mathrm{C}_{18}\left(4-n-\mathrm{C}_{5} \mathrm{H}_{11}-\mathrm{C}_{6} \mathrm{H}_{4}\right)_{6}$. The carbo-benzene $\mathrm{C}_{18}$ ring is actually the smallest cyclic primitive motif of $\alpha$-graphyne, and most of the derivatives reported hitherto bear only $\mathrm{H}$, aryl, or alkynyl substituents. ${ }^{6}$ Very recently, direct anchoring of alkyl chains at the $\mathrm{sp}^{2}$ vertices of the $\mathrm{C}_{18}$ ring was envisaged in a series of $p$-dialkyltetraphenyl-carbo-benzenes 1a-e, which could be obtained in two steps, by addition of alkylmagnesium bromides to the [6]pericyclynedione 2 followed by reductive aromatization of the [6]pericyclynediol products 3a-e (Scheme 1). ${ }^{7}$ The Grignard approach was however found not selective: beside the di-adducts 3a-e, the single and double reductions products $4 \mathbf{a}-\mathbf{e}$ (resulting from the mono-adduct) and $\mathbf{5}$ are also formed. The reducing power of alkyl Grignard reagents is actually known to be due to the presence of a $\mathrm{H}$ atom in $\beta$ position of the $\mathrm{Mg}$ atom, ${ }^{8}$ but several recommended methods to overcome this effect, e. g. through the change of solvent, failed to improve the reaction outcome. The use of alternative or additive metals should thus be envisaged.

Insert Scheme 1 here

In general nucleophilic addition of $\mathrm{Nu}-\mathrm{MX}$ to carbonyl groups, beyond lithium $(\mathrm{M}=$ $\mathrm{Li}, \mathrm{n}=0)$ and magnesium $(\mathrm{M}=\mathrm{Mg}, \mathrm{n}=1, \mathrm{X}=\mathrm{Br}, \mathrm{Cl}, \mathrm{I})$ cations, cerium cations $(\mathrm{M}=\mathrm{Ce}, \mathrm{n}=$ $2, \mathrm{X}=\mathrm{Cl}$ ) have also been reported to provide higher selectivity under smooth conditions. ${ }^{9}$ In the present context, targeting the [6]pericyclynediols $\mathbf{6 a - b}$ from the bis-terminal tetrayne $\mathbf{7 a - b}$ and dialdehyde $\mathbf{8}$, while reactions of the $\mathrm{MgBr}^{+}$salts alone appeared almost unproductive (0- 
$6 \%),{ }^{6 a, b, h}$, addition of $\mathrm{CeCl}_{3}$ was shown to improve the yield to $12-14 \%$, likely via the corresponding $\mathrm{CeCl}_{2}^{+}$salts (Scheme 2).

As part of ongoing efforts to improve access efficiency to carbo-benzene molecules, the study of the metal effect on the double nucleophilic addition to the diketone $\mathbf{2}$ has been undertaken for $\mathrm{Nu}=n$ - $\mathrm{Bu}$, a model nucleophile of intermediate length, with the view to obtaining the hitherto unknown representative $p$-di- $n$-butyl-tetraphenyl-carbo-benzene $\mathbf{1 f}$. This target, bearing both aliphatic and aromatic substituents, is also devised to serve as a standard for electrochemical studies in the carbo-benzene series.

\section{Insert Scheme 2 here}

\section{Experimental}

\section{General}

THF was dried with a PureSolv-MD-5 Innovative Technology system for the purification of solvents. All other reagents were used as commercially available. In particular, commercial solutions of $n$-BuLi were $2.5 \mathrm{M}$ in hexane, solutions of $\mathrm{HCl}$ were $2 \mathrm{M}$ in diethyl ether. All reactions were carried out under argon atmosphere using Schlenk tube and vacuum line techniques. Column chromatography was carried out on silica gel (60 A, C.C 70-200 $\mu \mathrm{m})$. Silica gel thin layer chromatography plates $(60 \mathrm{~F} 254,0.25 \mathrm{~mm})$ were revealed under UVlight and/or by treatment with an ethanolic solution of phosphomolybdic acid (20\%). The following analytical instruments were used: ${ }^{1} \mathrm{H}$ and ${ }^{13} \mathrm{C}$ NMR spectroscopy: Avance 300, Avance 400 and Avance 400 HD; mass spectrometry: Quadrupolar Nermag R10-10H; UVvisible absorption: Perkin-Elmer UV-Vis Win-Lab Lambda 950; X-ray diffraction: Apex2 Bruker, microfocus X-ray source (Mo K $\alpha$ radiation). NMR chemical shifts are given in ppm with positive values to high frequency relative to the tetramethylsilane reference. Coupling constants $J$ are in Hertz. UV-visible absorption wavelengths $\lambda$ is given in $\mathrm{nm}$, and the corresponding maximum extinction molar coefficient $\varepsilon$ in $\mathrm{Lmol}^{-1} \mathrm{~cm}^{-1}$.

\section{Crystal structure determination}

Intensity diffraction data for $1 \mathbf{f}$ were collected at $100 \mathrm{~K}$. The structure was solved by direct methods using SIR92, and refined by full-matrix least-square procedures on $F$ using the programs of the PC version of CRYSTALS. ${ }^{10}$ Atomic scattering factors were taken from the 
International Tables for X-ray Crystallography. ${ }^{11}$ All non-hydrogen atoms were refined anisotropically. Hydrogen atoms were refined using a riding model. Absorption corrections were introduced using the program MULTISCAN.

\section{Voltammetric measurements}

Voltammetric measurements were carried out with a potentiostat Autolab PGSTAT100 controled by GPES 4.09 software. Experiments were performed at room temperature in a home-made airtight three-electrode cell connected to a vacuum/argon line. The reference electrode consisted of a saturated calomel electrode (SCE) separated from the solution by a bridge compartment. The counter electrode was a platinum wire of $c a 1 \mathrm{~cm}^{2}$ apparent surface. The working electrode was a $\mathrm{Pt}$ microdisk $(0.5 \mathrm{~mm}$ diameter $)$. The supporting electrolyte $\left[n-\mathrm{Bu}_{4} \mathrm{~N}\right]\left[\mathrm{PF}_{6}\right]$ was used as received (Fluka, $99 \%$ electrochemical grade) and simply degassed under argon. The solutions used in the electrochemical study was $10^{-3} \mathrm{M}$ in carbo-benzene and $0.1 \mathrm{M}$ in supporting electrolyte. Before each measurement, the solutions are degassed by bubbling argon, and the working electrode was polished with a polishing machine (Presi P230). Typical instrumental parameters for recording square-wave voltammograms were: SW frequency $f=20 \mathrm{~Hz}, \mathrm{SW}$ amplitude $E_{\mathrm{sw}}=20 \mathrm{mV}$, scan increment $d E=5 \mathrm{mV}$.

\section{Experimental procedures and characterizations of new products}

4.1. 1,10-dibutyl-4,7,13,16-tetraphenylcyclooctadeca-1,2,3,7,8,9,13,14,15-nonaen5,11,17-triyne (1f)

A solution of [6]pericyclynediol $\mathbf{3 f}(50 \mathrm{mg}, 0.063 \mathrm{mmol})$ in DCM $(30 \mathrm{~mL})$ was treated with $\mathrm{SnCl}_{2}(120 \mathrm{mg}, 0.63 \mathrm{mmol})$ and $\mathrm{HCl}\left(1.26 \mathrm{mmol}, 2 \mathrm{M}\right.$ in $\left.\mathrm{Et}_{2} \mathrm{O}\right)$ at $-78{ }^{\circ} \mathrm{C}$. The mixture was stirred at $-78^{\circ} \mathrm{C}$ for $10 \mathrm{~min}$ and at room temperature for $20 \mathrm{~min}$. After treatment with $1 \mathrm{M}$ aqueous $\mathrm{NaOH}(1.26 \mathrm{~mL})$ and filtration through celite ${ }^{\circledR}$, the organic layer was washed with brine (3 times), dried over $\mathrm{MgSO}_{4}$, and concentrated under reduced pressure. The residue was purified by chromatography on silica gel (pentane/DCM 4:1) to give $\mathbf{1 f}$ as a dark violet solid (25 mg, $0.039 \mathrm{mmol}, 63 \%$ ).

${ }^{1} \mathbf{H}$ NMR $\left(400 \mathrm{MHz}, \mathrm{CDCl}_{3}\right) \delta 9.51\left(\mathrm{dd},{ }^{3} J_{\mathrm{HH}}=8.0,{ }^{4} J_{\mathrm{HH}}=1.2 \mathrm{~Hz}, 8 \mathrm{H}, o-\mathrm{C}_{6} H_{5}\right), 7.97(\mathrm{dd}$, $\left.{ }^{3} J_{\mathrm{HH}}=8.2,7.2 \mathrm{~Hz}, 8 \mathrm{H}, m-\mathrm{C}_{6} H_{5}\right), 7.73-7.66\left(\mathrm{~m}, 4 \mathrm{H}, p-\mathrm{C}_{6} H_{5}\right), 4.69\left(\mathrm{t},{ }^{3} J_{\mathrm{HH}}=7.5 \mathrm{~Hz}, 4 \mathrm{H}\right.$, 
$\mathrm{CH}_{2} \mathrm{Pr}$ ), 3.04-2.92 (m, 4H, $\left.\mathrm{CH}_{2} \mathrm{CH}_{2} \mathrm{Me}\right), 2.02-1.91$ (m, 4H, $\left.\mathrm{CH}_{2} \mathrm{Me}\right), 0.91-0.82(\mathrm{~m}, 6 \mathrm{H},-$ $\left.\mathrm{CH}_{3}\right)$.

${ }^{13} \mathbf{C}\left\{{ }^{1} \mathbf{H}\right\}$ NMR $\left(101 \mathrm{MHz}, \mathrm{CDCl}_{3}\right) \delta 139.9\left(i-C_{6} \mathrm{H}_{5}\right), 129.8\left(o-C_{6} \mathrm{H}_{5}\right), 129.8\left(m-C_{6} \mathrm{H}_{5}\right), 129.3$ $\left(p-C_{6} \mathrm{H}_{5}\right), 122.1,119.4,116.0(=C=C=,-C \equiv C-), 106.5(C-\mathrm{Bu}), 103.0(C-\mathrm{Ph}), 40.4\left(C_{2} \mathrm{Pr}\right)$, $34.0\left(\mathrm{CH}_{2} \mathrm{Et}\right), 22.8\left(\mathrm{CH}_{2} \mathrm{Me}\right), 14.3\left(-\mathrm{CH}_{3}\right)$.

HRMS (MALDI-TOF/DCTB): $m / z$ : $[\mathrm{M}]^{+}$calculated for $\mathrm{C}_{50} \mathrm{H}_{38}: 638.2974$, found: 638.3000; $[\mathrm{M}+\mathrm{Na}]^{+}$calculated for $\mathrm{C}_{50} \mathrm{H}_{38} \mathrm{Na}$ : 661.2871, found: 661.2931 .

UV-visible $\left(\mathrm{CHCl}_{3}\right): \lambda_{\max }=446.45 \mathrm{~nm}\left(\varepsilon=208000 \mathrm{~L} \cdot \mathrm{mol}^{-1} \cdot \mathrm{cm}^{-1}\right)$.

Melting-decomposition temperature: $188^{\circ} \mathrm{C}$.

4.2. 1-butyl-4,7,13,16-tetramethoxy-4,7,13,16-tetraphenylcyclooctadeca-2,5,8,11,14, 17-hexayne-1,10-diol (4f). Side-product obtained during the preparation of $\mathbf{3 f}$ (section 4.3.1).

${ }^{1} \mathbf{H}$ NMR $\left(400 \mathrm{MHz}, \mathrm{CDCl}_{3}\right) \delta$ 7.81-7.64 (m, 8H, o- $\left.\mathrm{C}_{6} H_{5}\right)$, 7.45-7.31 (m, 12H, m-, $\left.p-\mathrm{C}_{6} H_{5}\right)$, 5.43-5.24 (m, 1H, CHOH), 3.64-3.33 (m, 12H, $\left.\mathrm{OCH}_{3}\right), 2.91-2.31(\mathrm{~m}, 2 \mathrm{H}, \mathrm{OH}), 2.07-1.95(\mathrm{~m}$, $\left.2 \mathrm{H}, \mathrm{CH}_{2} \mathrm{Pr}\right), 1.76-1.60$ (m, 2H, $\left.\mathrm{CH}_{2} \mathrm{Et}\right), 1.41-1.30$ (m, $\left.2 \mathrm{H}, \mathrm{CH}_{2} \mathrm{Me}\right), 0.93-0.82\left(\mathrm{~m}, 3 \mathrm{H}, \mathrm{CH}_{3}\right)$.

${ }^{13} \mathbf{C}\left\{{ }^{1} \mathbf{H}\right\}$ NMR $\left(101 \mathrm{MHz}, \mathrm{CDCl}_{3}\right) \delta 139.48\left(i-C_{6} \mathrm{H}_{5}\right), 129.10\left(p-C_{6} \mathrm{H}_{5}\right), 128.53\left(m-C_{6} \mathrm{H}_{5}\right)$, $126.46\left(o-C_{6} \mathrm{H}_{5}\right), 87.10,84.67,82.91$ (-C $\equiv C$-) , 75.96, 72.98 (C(OMe)-Ph)), $63.71(C(\mathrm{OH})-$ $\mathrm{Bu}), 53.36$ - $53.31\left(\mathrm{OCH}_{3}\right), 53.26(>\mathrm{CHOH}), 42.82\left(\mathrm{CH}_{2} \mathrm{Pr}\right), 26.66\left(\mathrm{CH}_{2} \mathrm{Et}\right), 22.35\left(\mathrm{CH}_{2} \mathrm{Me}\right)$, $11.41\left(\mathrm{CH}_{2} \mathrm{CH}_{3}\right)$.

HRMS (MALDI-TOF/DCTB): $m / z$ : [M+Na] + calculated for $\mathrm{C}_{50} \mathrm{H}_{44} \mathrm{O}_{6} \mathrm{Na}: 763.3036$, found: 763.3085 .

4.3. 1,10-dibutyl-4,7,13,16-tetramethoxy-4,7,13,16-tetraphenylcyclooctadeca2,5,8,11,14,17-hexayne-1,10-diol (3f)

\subsubsection{Procedure for the preparation of $\mathbf{3 f}$ with $n-B u M g B r$}

To a suspension of magnesium turnings $(3.2 \mathrm{mg}, 0.1324 \mathrm{mmol})$ in THF $(0.5 \mathrm{~mL})$ at room temperature was added dropwise $n-\mathrm{BuBr}(0.057 \mathrm{~mL}, 0.5296 \mathrm{mmol})$. The mixture was stirred for $2 \mathrm{~h}$ at room temperature. A solution of [6]pericyclynedione 2 (30 $\mathrm{mg}, 0.044 \mathrm{mmol}$ ) in THF $(5 \mathrm{~mL})$ at $0{ }^{\circ} \mathrm{C}$ was treated with the freshly prepared solution of $n$-BuMgBr. The 
mixture was stirred at $0{ }^{\circ} \mathrm{C}$ for $3 \mathrm{~h}$ before treatment with a saturated aqueous solution of $\mathrm{NH}_{4} \mathrm{Cl}$. The aqueous layer was extracted with diethyl ether, and the combined organic layers were dried over $\mathrm{MgSO}_{4}$ and concentrated under reduced pressure. The residue was purified by chromatography on silica gel (pentane/EtOAc 5:1, then 3:1) to give the di-adduct $\mathbf{3 f}$ (18 $\mathrm{mg}$, $0.0226 \mathrm{mmol}, 51 \%)$, the mono-adduct $4 \mathbf{f}(9 \mathrm{mg}, 0.012 \mathrm{mmol}, 28 \%)$, and the known direduction diol product 5 (5 mg, $0.007 \mathrm{mmol}, 16 \%),{ }^{6 \mathrm{~h}, 11}$ as yellow oils. Characterization of $\mathbf{3 f}$ : see section 4.3.4. Characterization of $\mathbf{4 f}$ : see section 4.2.

\subsubsection{Procedure for the preparation of $\mathbf{3 f}$ with $n-\mathrm{BuMgCl}$}

A solution of [6]pericyclynedione $2(40 \mathrm{mg}, 0.0588 \mathrm{mmol})$ in $\mathrm{THF}(6 \mathrm{~mL})$ at $0{ }^{\circ} \mathrm{C}$ was treated with commercial $n$ - $\mathrm{BuMgCl}(0.176 \mathrm{mmol}, 2 \mathrm{M}$ in diethyl ether). The mixture was stirred at $0{ }^{\circ} \mathrm{C}$ for $1 \mathrm{~h}$, then at room temperature for $3 \mathrm{~h}$ before treatment with a saturated aqueous solution of $\mathrm{NH}_{4} \mathrm{Cl}$. The aqueous layer was extracted with diethyl ether, and the combined organic layers were dried over $\mathrm{MgSO}_{4}$ and concentrated under reduced pressure. The residue was purified by chromatography on silica gel (pentane/EtOAc 5:1, then 3:1) to give the di-adduct $\mathbf{3 f}$ as a yellow oil (25 mg, $53 \%$ ). Characterization of $\mathbf{3 f}$ : see section 4.3.4.

\subsubsection{Procedure for the preparation of $\mathbf{3} \mathbf{f}$ with $n-B u L i$}

A solution of [6]pericyclynedione $2(40 \mathrm{mg}, 0.059 \mathrm{mmol})$ in THF $(6 \mathrm{~mL})$ at $-78{ }^{\circ} \mathrm{C}$ was treated with $n$-BuLi $(0.1176 \mathrm{mmol}, 2.5 \mathrm{M}$ in hexane). The mixture was stirred while slowly warming up to $-30{ }^{\circ} \mathrm{C}$ over $1.5 \mathrm{~h}$ before addition of an aqueous solution of $\mathrm{NH}_{4} \mathrm{Cl}$. The aqueous layer was extracted with diethyl ether, and the combined organic layers were dried over $\mathrm{MgSO}_{4}$ and concentrated under reduced pressure. The residue was purified by chromatography on silica gel (pentane/EtOAc 5:1) to give $\mathbf{3 f}$ as a yellow oil (33 $\mathrm{mg}, 0.041$ mmol, $70 \%$ ). Characterization of $\mathbf{3 f}$ : see section 4.3.4.

\subsubsection{Procedure for the preparation of $\mathbf{3 f}$ with $n-B u L i$ and $\mathrm{CeCl}_{3}$}

To a suspension of $\mathrm{CeCl}_{3}(37 \mathrm{mg}, 0.147 \mathrm{mmol})$ in THF $(10 \mathrm{~mL})$ at $-78{ }^{\circ} \mathrm{C}$ was added $n$-BuLi (0.147 mmol, 2.5 $\mathrm{M}$ in hexane) and the resulting mixture was stirred for $0.5 \mathrm{~h}$ at this temperature. After treatment with a solution of [6]pericyclynedione $2(50 \mathrm{mg}, 0.0735 \mathrm{mmol})$ in THF $(8 \mathrm{~mL})$ at $-78{ }^{\circ} \mathrm{C}$, the mixture was slowly warmed up to $-20{ }^{\circ} \mathrm{C}$ during $2 \mathrm{~h}$ before addition of an aqueous solution of $\mathrm{NH}_{4} \mathrm{Cl}$. The aqueous layer was extracted with diethyl ether, and the combined organic layers were dried over $\mathrm{MgSO}_{4}$ and concentrated under reduced 
pressure. The residue was purified by chromatography on silica gel (pentane/EtOAc 5:1) to give $3 \mathbf{f}$ as a yellow oil (53 $\mathrm{mg}, 0.067 \mathrm{mmol}, 90 \%)$.

${ }^{1} \mathbf{H}$ NMR $\left(300 \mathrm{MHz}, \mathrm{CDCl}_{3}\right) \delta$ 7.81-7.64 (m, 8H, o- $\left.\mathrm{C}_{6} H_{5}\right)$, 7.45-7.30 (m, 12H, m-, $\left.p-\mathrm{C}_{6} H_{5}\right)$, 3.73-3.21 (m, 12H, $\left.\mathrm{OCH}_{3}\right), 3.04-2.51(\mathrm{~m}, 2 \mathrm{H}, \mathrm{OH}), 2.10-1.89$ (m, 4H, CH $\left.\mathrm{C}_{2} \mathrm{Pr}\right), 1.78-1.51$ (m, $\left.4 \mathrm{H}, \mathrm{CH}_{2} \mathrm{Et}\right), 1.39-1.23\left(\mathrm{~m}, 4 \mathrm{H}, \mathrm{CH}_{2} \mathrm{Me}\right), 1.00-0.81\left(\mathrm{~m}, 6 \mathrm{H}, \mathrm{CH}_{2} \mathrm{CH}_{3}\right)$.

${ }^{13} \mathbf{C}\left\{{ }^{1} \mathbf{H}\right\}$ NMR $\left(75 \mathrm{MHz}, \mathrm{CDCl}_{3}\right) \delta$ 139.6-139.3 $\left(i-C_{6} \mathrm{H}_{5}\right), 129.1-129.0\left(p-C_{6} \mathrm{H}_{5}\right), 128.5-128.4$ $\left(m-C_{6} \mathrm{H}_{5}\right), \quad 126.5-126.4 \quad\left(o-C_{6} \mathrm{H}_{5}\right), \quad 87.4-87.0, \quad 84.5-84.3, \quad 81.2-80.1 \quad(-C \equiv C-), \quad 71.9-71.8$ (C(OMe)-Ph), $63.7(C(\mathrm{OH})-\mathrm{Bu}), 53.4-53.3\left(\mathrm{OCH}_{3}\right), 43.0-42.8\left(\mathrm{CH}_{2} \mathrm{Pr}\right), 26.8-26.5\left(\mathrm{CH}_{2} \mathrm{Et}\right)$, 22.4-22.3 $\left(\mathrm{CH}_{2} \mathrm{Me}\right)$, 14.2-13.9 $\left(\mathrm{CH}_{2} \mathrm{CH}_{3}\right)$.

HRMS (MALDI-TOF/DCTB): $m / z$ : $[\mathrm{M}+\mathrm{H}]^{+}$calculated for $\mathrm{C}_{54} \mathrm{H}_{53} \mathrm{O}_{6}:$ 797.3842, found: 797.3771 .

\section{Results and discussion}

$p$-Di- $n$-butyl-tetraphenyl-carbo-benzene 1f was targeted through the classical route, i.e. by reductive aromatization of the corresponding [6]pericyclynediol $\mathbf{3 f}$, itself envisaged from the [6]pericyclynedione 2 and various $n-\mathrm{Bu}-\mathrm{MX}_{\mathrm{n}}$ reagents, $\mathrm{MX}_{\mathrm{n}}=\mathrm{MgBr}, \mathrm{MgCl}, \mathrm{Li}$, $\mathrm{CeCl}_{2}$ (Scheme 3). ${ }^{12}$

Following previous experiences (Scheme 1), addition of two equivalents of $n$ butylmagnesium bromide to $\mathbf{2}$ gave $\mathbf{3 f}$ in $51 \%$ yield, along with the reduced mono-adduct $\mathbf{4 f}$ and the known bis-secondary [6]pericyclynediol $5,{ }^{6 \mathrm{~h}, 13}$ isolated in $28 \%$ and $16 \%$ yield, respectively.

Replacing $n$-BuMgBr by $n$-BuMgCl led to the diadduct $3 f$ with a similar $53 \%$ yield, but without reduction side-product, as indicated by the absence of any $\mathrm{CHOH}{ }^{1} \mathrm{H}$ NMR signal in the range 5-6 ppm. This change in nucleophilic $v s$ redox selectivity can be attributed to the electronegativity-driven higher nucleophilic reactivity of the chlorinated magnesium salt as compared to the brominated congener. Traces of the non-reduced mono-ketone mono-adduct were detected by ${ }^{1} \mathrm{H}$ NMR spectroscopy, but could not be separated from other unidentified products, likely polymeric in nature.

Addition of two equivalents of $n$-butyllithium to 2 followed by aqueous quenching at $30^{\circ} \mathrm{C}$ was found to proceed selectively, allowing the diadduct $3 \mathrm{f}$ to be isolated in $70 \%$ yield. This result contrasts with the poor efficiency of the addition of aryllithium reagents to the same diketone $\mathbf{2}$, the intermediate lithium alkoxide evolving by retro-additive opening of the 
macrocycle towards stabilized arylketones such as $\mathbf{9}$ (Scheme 3$).{ }^{14}$ Such a ring opening was not observed with $n$-BuLi, provided that the reaction mixture was quenched at $-30{ }^{\circ} \mathrm{C}$.

Finally, addition of two equivalents of $n$-butylcerium dichloride, assumed to be formed in situ from $n$-BuLi and dry $\mathrm{CeCl}_{3}$, to $\mathbf{2}$ was found to proceed very selectively, affording the [6]pericyclynediol $\mathbf{3 f}$ with a $90 \%$ isolated yield. This result is in line with the ones disclosed above $(\mathrm{M}=\mathrm{Li}>\mathrm{Mg}, \mathrm{X}=\mathrm{Cl}>\mathrm{Br})$, and with previous reports on the general use of cerium reagents. ${ }^{6 \mathrm{a}-\mathrm{b}, 9}$

\section{Insert here the Scheme 3}

The target di-n-butyl-tetraphenyl-carbo-benzene 1f was finally obtained by classical reductive treatment of the [6]pericyclynediol 3f with $\mathrm{SnCl}_{2}$ and $\mathrm{HCl}$ in dichloromethane (DCM). ${ }^{6}$ It was isolated with $63 \%$ yield as a stable dark red solid, soluble in chlorinated organic solvents (chloroform and DCM).

Single crystals of 1f deposited from a DCM solution were analyzed by X-ray diffraction, confirming the anticipated structure (Figure 1). The $\mathrm{C}_{18}$ macrocycle of $\mathbf{1 f}$ is quasiplanar with a quasi-regular hexagonal shape, the maximal deviation from planarity being of $0.028 \AA$. The measured bond lengths in the $\mathrm{C}_{18}$ ring are classical for a carbo-benzene ( $s p \mathrm{C}$ $s p \mathrm{C} \approx 1.22-1.23 \AA, s p^{2} \mathrm{C}-s p \mathrm{C} \approx 1.37-1.38 \AA$ ). The $n$-butyl chains exhibit a zig-zag arrangement almost perfectly coplanar with the $\mathrm{C}_{18}$ ring, as previously observed for some dialkyl-carbo-benzenes. ${ }^{7 \mathrm{a}}$ Two of the phenyl substituents are also quasi-coplanar with the $\mathrm{C}_{18}$ ring, while the two others adopt a torsion angle of $c a 25^{\circ}$. The distance between two successive $\mathrm{C}_{18}$ mean planes is $3.445 \AA$, which is longer than the shortest corresponding distance of $3.206 \AA$ measured for the bis-tetradecyl-carbo-benzene: no direct $\pi-\pi$ stacking between $\mathrm{C}_{18}$ rings of $\mathbf{1 f}$ is observed in the crystal, where co-crystallized DCM molecules prevent van der Waals contact between nearest macrocycles. ${ }^{7 \mathrm{a}}$

\section{Insert here the Figure 1}

The dibutyl-carbo-benzene 1f was also characterized by ${ }^{1} \mathrm{H}$ and ${ }^{13} \mathrm{C} \mathrm{NMR}$ in $\mathrm{CDCl}_{3}$ solution. The ${ }^{1} \mathrm{H}$ NMR spectral profile is similar to those reported for other dialkyl-carbobenzenes, with a strong deshielding at $9.51 \mathrm{ppm}$ of the $o-\mathrm{CH}$ nuclei of the four equivalents 
phenyl substituents. ${ }^{7 \mathrm{a}}$ This effect reveals the strength of the diatropic $\mathrm{C}_{18}$ ring current, which also affects the ${ }^{1} \mathrm{H}$ signals of the $n$-butyl chain, progressively vs the distance of the $\mathrm{CH}_{2}$ groups to the $\mathrm{C}_{18}$ ring border, as previously analyzed for other $n$-alkyl-carbo-benzenes (Figure $\mathrm{S} 1$ in the S.I.). ${ }^{7 \mathrm{a}}$

The UV-vis absorption pattern of $\mathbf{1 f}$ in chloroform solution is classical for dialkyltetraphenyl-carbo-benzenes $\left(\lambda_{\max }=446 \pm 0.5 \mathrm{~nm}\right)$, with one main band at $446 \mathrm{~nm}$, accompanied by three smaller bands at higher wavelength (Figure S2 in the S.I.). ${ }^{7 \mathrm{a}}$ The chromophoric intensity of $\mathbf{1 f}$ is also classical in this series, with a maximum extinction coefficient of $208000 \mathrm{~L} \cdot \mathrm{mol}^{-1} \cdot \mathrm{cm}^{-1}$.

The title target $1 \mathbf{f}$ has been selected as a model for an analysis of the solvent effect on the electrochemical behavior of carbo-benzene derivatives, that might be not soluble enough in DCM to allow the study of redox properties in this solvent, requiring the use of chloroform instead. ${ }^{15}$ For the sake of comparison, solutions of $\mathbf{1 f}$ in both chloroform and DCM were thus investigated by square-wave (SW) and cyclic (CV) voltammetry (Table 1).

In the reference DCM solvent, $\mathbf{1 f}$ lends itself to three successive reduction processes, two of them being reversible at $E_{1 / 2}{ }^{\text {red }}=-0.82 \mathrm{~V}$ and $-1.26 \mathrm{~V}$, those values being comparable to those previously reported for other carbo-benzene derivatives. ${ }^{6 f, 6 i, 15}$ The aromaticity of the $\mathrm{C}_{18}$ ring indeed attenuates its sensitivity to substituents. ${ }^{6 f}$ In chloroform, the two first reductions occur at similar potentials (albeit turning less reversible at $-0.82 \mathrm{~V},-1.32 \mathrm{~V}$ ), while the third reduction peak occurring at $E_{\mathrm{p}}{ }^{\text {red }}=-1.98 \mathrm{~V}$ in DCM cannot be detected because of the narrower electrochemical observation window of $\mathrm{CHCl}_{3}$, which is reduced at this potential. These results also show that replacement of two aryl substituents by alkyl counterparts has a weak but electronically consistent effect on the reduction potential values $\left(-0.72 \mathrm{~V},-1.15 \mathrm{~V}\right.$ for hexaphenyl-carbo-benzene). ${ }^{15}$

In both solvents, three oxidation processes are also observed at comparable potentials, with a loss of reversibility of the second wave observed in DCM $\left(E_{1 / 2}{ }^{\text {ox }}=+1.63 \mathrm{~V}\right)$ by passing to chloroform $\left(E_{\mathrm{P}}{ }^{\text {ox2 }}=+1.69 \mathrm{~V}\right)$.

The influence of the solvent on the redox potentials is thus limited, but affects the reversibility of the processes, possibly because of the higher viscosity and lower dielectric constant of chloroform $\left(\eta\left(\mathrm{CHCl}_{3}\right)=0.537 \mathrm{mPa} . \mathrm{s}>\eta(\mathrm{DCM})=0.413 \mathrm{mPa} . \mathrm{s}, \varepsilon\left(\mathrm{CHCl}_{3}\right)=4.81\right.$ $<\varepsilon(\mathrm{DCM})=8.93)$. A high dielectric constant indeed favors charge dissociation thus enhancing the conductivity of the electrolytic solution. 


\begin{tabular}{|c|c|c|c|c|c|c|c|}
\hline \multirow{2}{*}{\multicolumn{2}{|c|}{$\begin{array}{c}\text { solvent } \\
\text { / redox event no }\end{array}$}} & \multicolumn{3}{|c|}{ reductions } & \multicolumn{3}{|c|}{ oxidations } \\
\hline & & $E_{1 / 2}^{\mathrm{a}}\left(\Delta E_{\mathrm{P}}\right)^{\mathrm{b}}$ & $\mathrm{R} I_{\mathrm{P}}^{\mathrm{c}}$ & $E_{\mathrm{P}}{ }^{\text {red d }}$ & $E_{1 / 2}^{\mathrm{a}}\left(\Delta E_{\mathrm{P}}\right)^{\mathrm{b}}$ & $\mathrm{R} I_{\mathrm{P}}^{\mathrm{c}}$ & $E_{\mathrm{P}}{ }^{\text {ox d }}$ \\
\hline \multirow[t]{3}{*}{ DCM } & $1 \mathrm{st}$ & $-0.82(68)$ & 0.97 & & $1.15(78)$ & 1.04 & \\
\hline & 2nd & $-1.26(63)$ & 0.97 & & $1.63(107)$ & 1.15 & \\
\hline & $3 \mathrm{rd}$ & & & -1.98 & & & 2.06 \\
\hline \multirow[t]{3}{*}{$\mathrm{CHCl}_{3}$} & $1 \mathrm{st}$ & $-0.82^{\mathrm{e}}(59)$ & 1.01 & & $1.18^{\mathrm{e}}(53)$ & 0.68 & \\
\hline & 2nd & & & -1.32 & & & 1.69 \\
\hline & $3 \mathrm{rd}$ & & & $\mathrm{f}$ & & & 2.05 \\
\hline
\end{tabular}

Table 1. Voltammetric data for $1 f$ in DCM and chloroform solutions. Supporting electrolyte: solvent $+0.1 \mathrm{M}[\mathrm{TBA}]\left[\mathrm{PF}_{6}\right]$; scan rate: $0.2 \mathrm{~V} / \mathrm{s} .{ }^{\mathrm{a}}$ Half-wave potential $E_{1 / 2}=\left(E_{\mathrm{P}}{ }^{\text {red }}\right.$ $\left.+E_{\mathrm{P}}{ }^{\mathrm{ox}}\right) / 2$, in V/SCE. ${ }^{\mathrm{b}}$ Separation between the two peak potentials: $\Delta E_{\mathrm{P}}=\left|E_{\mathrm{P}}{ }^{\text {red }}-E_{\mathrm{P}}{ }^{\mathrm{ox}}\right|$, in V. ${ }^{\mathrm{c}}$ Peak current ratio $\mathrm{R} I_{\mathrm{P}}=\left|\mathrm{I}_{\mathrm{P}}{ }^{\mathrm{ox}} / \mathrm{I}_{\mathrm{P}}{ }^{\text {red }}\right|^{\mathrm{d}} E_{\mathrm{P}}$ values measured from $\mathrm{CV}$ in V/SCE. ${ }^{\mathrm{e}}$ Reversibility observed at high scan rates only. ${ }^{\mathrm{f}}$ The third reduction cannot be observed in $\mathrm{CHCl}_{3}$ because the solvent is reduced at this potential.

\section{Conclusion}

The metal switch study of the reaction of a model alkyl nucleophile with the [6]pericyclynedione 2 brings out the dichlorocerium(III) reagent as the most selective for the production of 3f. The improvement is particularly eloquent by comparison to the bromomagnesium reagent affording also the double reduction product $\mathbf{5}$ and the single addition/reduction product $\mathbf{4 f}$ (that could however be profitably used for a carbo-benzene library purpose). ${ }^{7 \mathrm{a}}$ The synthesis results provide a global increase of the yield of preparation of $p$-di- $n$-butyl-tetraphenyl-carbo-benzene 1f, from $32 \%$ to $57 \%$ over the two last steps. The cerium method can thus henceforth be envisaged for the synthesis of other alkyl-carbobenzenes.

The disclosed voltammetry results, the first ones in the alkyl-carbo-benzene series, indicate that the electrochemical behavior of carbo-benzenes is little sensitive to solvent (DCM vs chloroform) and substituent (alkyl vs aryl) effects. More generally, the "hybrid" member of the carbo-benzene family 1f, with two standard alkyl chain and four phenyl ring substituents, could now serve as a soluble standard for other comparative studies. 


\section{Acknowledgements}

C. Z. thanks the China Scholarship Council for his Ph.D. scholarship. The ANR program (ANR-11-BS07-016-01) is acknowledged for funding. R. C. thanks the Centre National de la Recherche Scientifique (CNRS) for half a teaching sabbatical in 2015-2016.

Supporting Information: ${ }^{1} \mathrm{H}$ NMR and UV-vis. absorption spectra of $\mathbf{1 f}$.

\section{References}

(1) (a) Baughman, R. H.; Eckhardt, H.; Kertesz, M. J. Chem. Phys., 1987, 87, 6687-6699; (b) Malko, D.; Neiss, C.; Vines, F.; Gorling, A. Phys. Rev. Lett. 2012, 108, 086804-1/4; (c) Kim, B. G.; Choi, H. J. Phys. Rev. B 2012, 86, 115435-1/5; (d) Ducere, J.-M.; Lepetit, C.; Chauvin, R. J. Phys. Chem. C 2013, 117, 21671-21681; (e) Ivanovskii, A. L. Progr. Solid State Chem. 2013, 41, 1-19; (f) Han, N.; Liu, H.; Zhou, S.; Zhao, J. J. Phys. Chem. C 2016, 120, 1469914705.

(2) (a) Kehoe, J. M.; Kiley, J. H.; English, J. J.; Johnson, C. A.; Petersen, R. C.; Haley, M. M. Org. Lett. 2000, 2, 969-972; (b) Yoshimura, T.; Inaba, A.; Sonoda, M.; Tahara, K.; Tobe, Y.; Williams, R. V. Org. Lett. 2006, 8, 2933-3936; (c) Johnson II, C. A.; Lu, Y.; Haley, M. M. Org. Lett. 2007, 9, 3725-3728; (d) Haley, M. M. Pure Appl. Chem. 2008, 80, 519-532.

(3) (a) Wan, W. B.; Haley, M. M. J. Org. Chem. 2001, 66, 3893-3901; Marsden, J. A.; Haley, M. M. J. Org. Chem. 2005, 70, 10213-10226.

(4) Cocq, K.; Saffon-Merceron, N.; Coppel, Y.; Poidevin, C.; Maraval, V.; Chauvin, R. Angew. Chem. Int. Ed., 2016, 55, 15133-15136.

(5) (a) Chauvin, R. Tetrahedron Lett. 1995, 36, 397-400; (b) Maraval, V.; Chauvin, R. Chem. Rev. 2006, 106, 5317-5343.

(6) For references on carbo-benzenes see: (a) Kuwatani, Y.; Watanabe, N.; Ueda, I. Tetrahedron Lett. 1995, 36, 119-122; (b) Suzuki, R.; Tsukude, H.; Watanabe, N.; Kuwatani, Y.; Ueda, I. Tetrahedron 1998, 54, 2477-2496; (c) Saccavini, C.; Sui-Seng, C.; Maurette, L.; Lepetit, C.; Soula, S.; Zou, C.; Donnadieu, B.; Chauvin, R. Chem. Eur. J. 2007, 13, 49144931; (d) Zou, C.; Duhayon, C.; Maraval, V.; Chauvin, R. Angew. Chem. Int. Ed. 2007, 46, 4337-4341; (e) Leroyer, L.; Lepetit, C.; Rives, A.; Maraval, V.; Saffon-Merceron, N.; 
Kandaskalov, D.; Kieffer, D.; Chauvin, R. Chem. Eur. J. 2012, 18, 3226-3240; (f) Rives, A.; Baglai, I.; Malytskyi, V.; Maraval, V.; Saffon-Merceron, N.; Voitenko, Z.; Chauvin, R. Chem. Commun. 2012, 48, 8763-8765; (g) Baglai, I.; Maraval, V.; Bijani, C.; Saffon-Merceron, N.; Voitenko, Z.; Volovenko, Y. M.; Chauvin, R. Chem. Commun. 2013, 49, 8374-8376; (h) Cocq, K.; Maraval, V.; Saffon-Merceron, N.; Chauvin, R. Chem. Rec. 2015, 15, 347-361; (i) Cocq, K.; Lepetit, C.; Maraval, V.; Chauvin, R. Chem. Soc. Rev. 2015, 44, 6535-6559; (j) Baglai, I.; de Anda-Villa, M.; Barba-Barba, R. M.; Poidevin, C.; Ramos-Ortíz, G.; Maraval, V.; Lepetit, C.; Saffon-Merceron, N.; Maldonado, J.-L.; Chauvin, R. Chem. Eur. J. 2015, 21, 14196-14195; (k) Cocq, K.; Saffon-Merceron, N.; Maraval, V.; Chauvin, R. Synlett, 2016, 27, 2105-2112.

(7) (a) Zhu, C.; Rives, A.; Duhayon, C.; Maraval, V.; Chauvin, R. J. Org. Chem., 2017, 82, 925-935. For references on pericyclynes see: (b) Scott, L. T.; DeCicco, G. J.; Hyun J. L.; Reinhardt, G. J. Am. Chem. Soc., 1983, 105, 7760-7761; (c) Scott, L. T.; DeCicco, G. J.; Hyun J. L.; Reinhardt, G. J. Am. Chem. Soc., 1985, 107, 6546-6555.

(8) (a) Morrisson, J. D.; Tomaszewski, J. E.; Mosher, H. S.; Dale, J.; Miller D.; Elsenbaumer, R. L. J. Am. Chem. Soc., 1977, 99, 3167-3168; (b) Ashby E. C., Goel, A. B. J. Am. Chem. Soc., 1981, 103, 4983-4985

(9) For early references see: (a) Imamoto, T.; Kusumoto, T.; Yokoyama, M. J. Chem. Soc., Chem. Commun., 1982, 1042-1044; (b) Imamoto, T.; Sugiura, Y.; Takiyama, N. Tetrahedron Lett. 1984, 25, 4233-4236. For a recent review see: (c) Bartoli, G.; Marcantoni, E.; Marcolini, M.; Sambri, L. Chem. Rev., 2010, 110, 6104-6143.

(10) Betteridge, P. W.; Carruthers, J. R.; Cooper, R. I.; Prout K.; Watkin, D. J. J. Appl. Cryst., 2003, 36, 1487.

(11) International Tables for X-ray Crystallography, vol. IV, Kynoch Press, Birmingham, England, 1974.

(12) (a) Maurette, L.; Tedeschi, C.; Sermot, E.; Soleilhavoup, M.; Hussain, F.; Donnadieu, B.; Chauvin, R. Tetrahedron 2004, 60, 10077-10098; (b) Leroyer, L.; Zou, C.; Maraval, V.; Chauvin, R. C. R. Chimie, 2009, 12, 412-429.

(13) Saccavini, C.; Tedeschi, C.; Maurette, L.; Sui-Seng, C.; Zou, C.; Soleilhavoup, M.; Vendier, L.; Chauvin, R. Chem. Eur. J. 2007, 13, 4895-4913.

(14) Zhu, C.; Maraval, V; Chauvin, R. unpublished results.

(15) Zhu, C.; Duhayon, C.; Romero-Borja, D.; Maldonado, J.-L.; Ramos-Ortíz, G.; Saquet, A.; Maraval, V.; Chauvin, R., submitted for publication. 


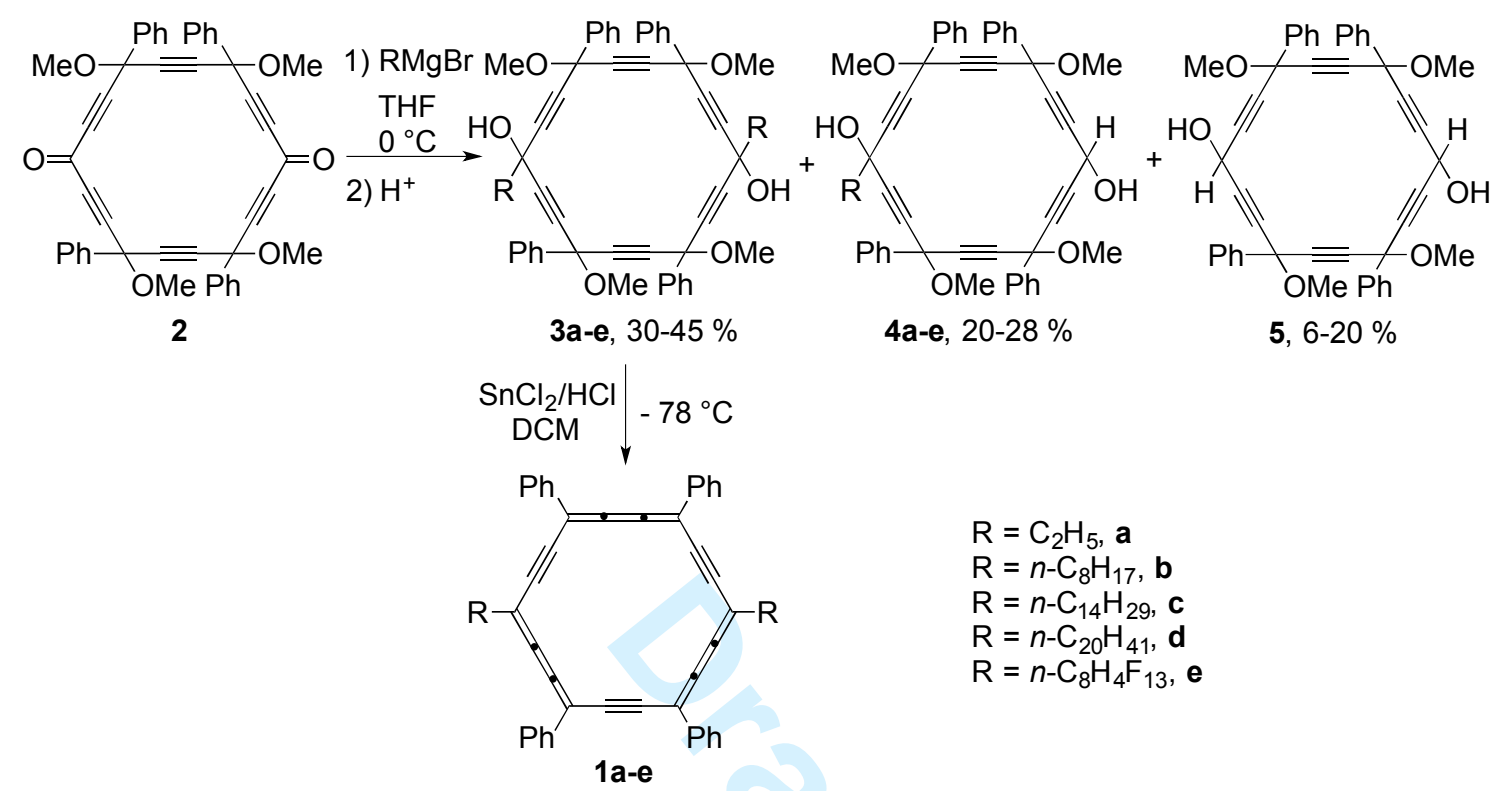

Scheme 1. Last two steps of previous syntheses of $p$-dialkyl-carbo-benzenes. The intermediates 2-5 were used as mixtures of stereoisomers.<smiles>[R]C(C#CC(C#CC(C#CC(OC)(c1ccccc1)c1ccccc1)(c1ccccc1)c1ccccc1)(c1ccccc1)c1ccccc1)(c1ccccc1)c1ccccc1</smiles>

7a: $R=T H P$

$7 \mathrm{~b}: \mathrm{R}=\mathrm{Me}$
1) $2 \mathrm{EtMgBr}$

2) $\mathrm{CeCl}_{3}$, x equiv.<smiles>COC(C#CC=O)(c1ccccc1)c1ccccc1</smiles>

4) $\mathrm{H}^{+}$

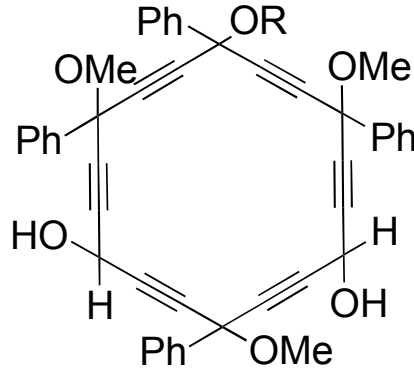

$\mathrm{Ph} \mathrm{OMe}$

\begin{tabular}{lll}
\hline$x$ (equiv. $\left.\mathrm{CeCl}_{3}\right)$ & 0 & 2 \\
\hline 6a: $\mathrm{R}=\mathrm{THP}$ & $6 \%$ & $14 \%$ \\
6b: $\mathrm{R}=\mathrm{Me}$ & $0 \%$ & $12 \%$
\end{tabular}

Scheme 2. Improvement of a [11+7] macrocyclization from a C11 tetrayne and a C7 dialdehyde through the use of a cerium(III) reagent. 


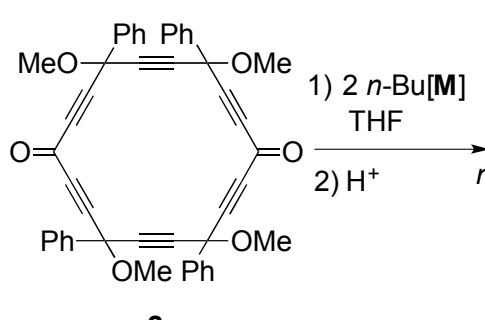

2
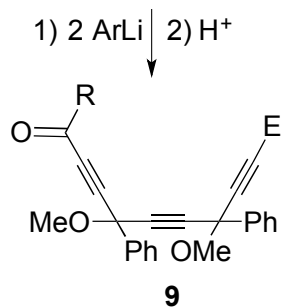

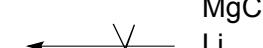
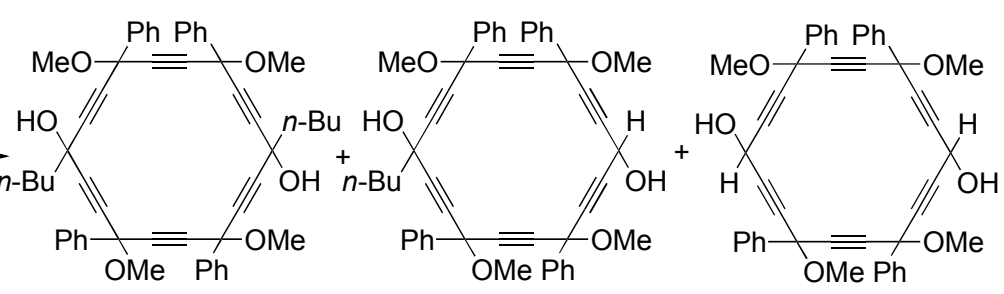

$$
\begin{gathered}
\mathrm{R}=\mathrm{Ar}(\text { aromatic }): \\
\mathrm{E}=\mathrm{C}(\mathrm{Ar})=\mathrm{O} \text { or } \mathrm{H} \\
\text { main products }
\end{gathered}
$$

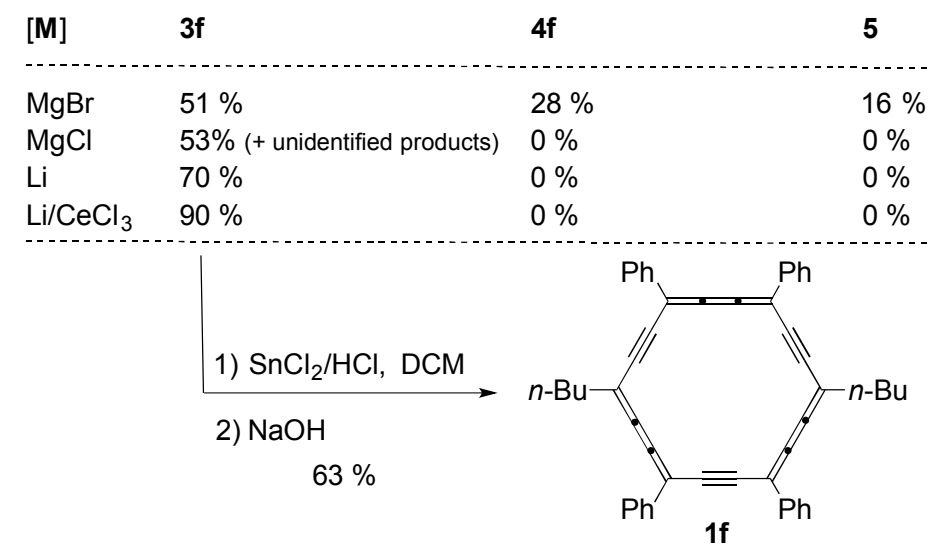

Scheme 3. En route and access to $p$-di-n-butyl-tetraphenyl-carbo-benzene.

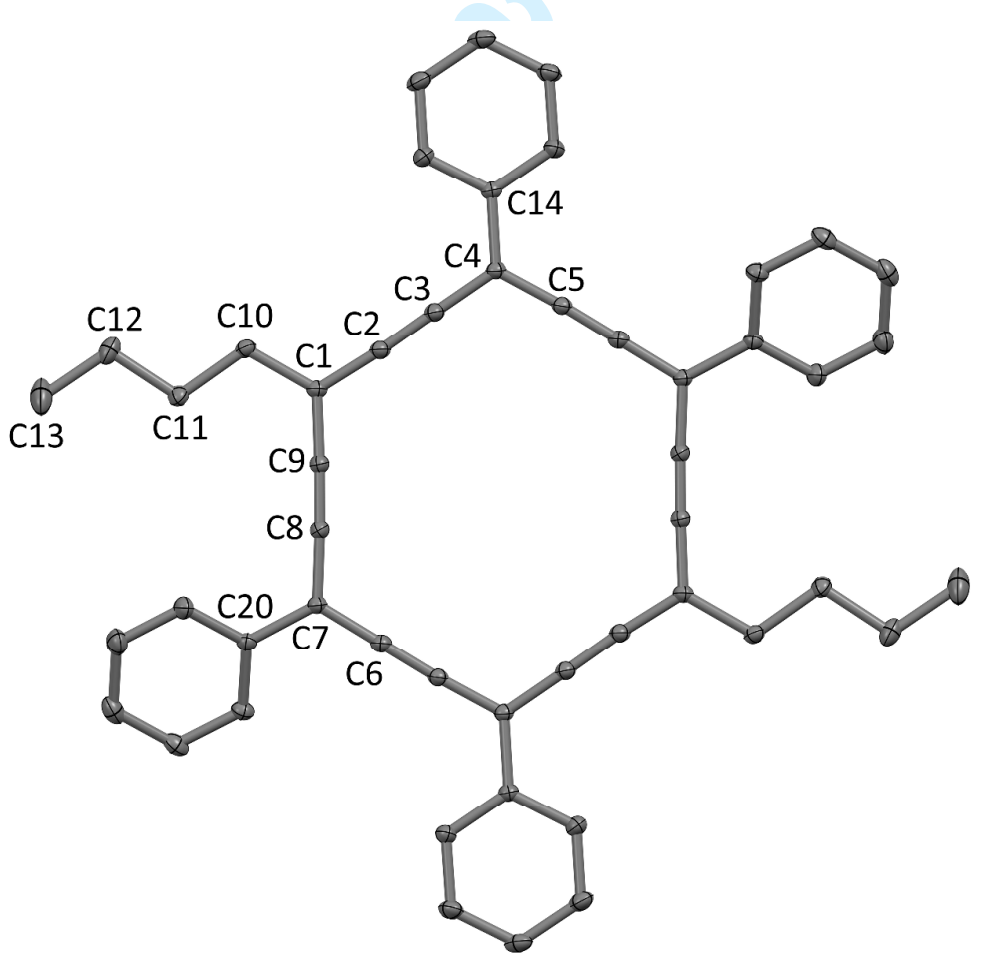

Figure 1. Molecular view of the X-ray crystal structure of 1f. Thermal ellipsoids at the $50 \%$ probability level. For clarity, hydrogen atoms are omitted. 
GRAPHICAL ABSTRACT

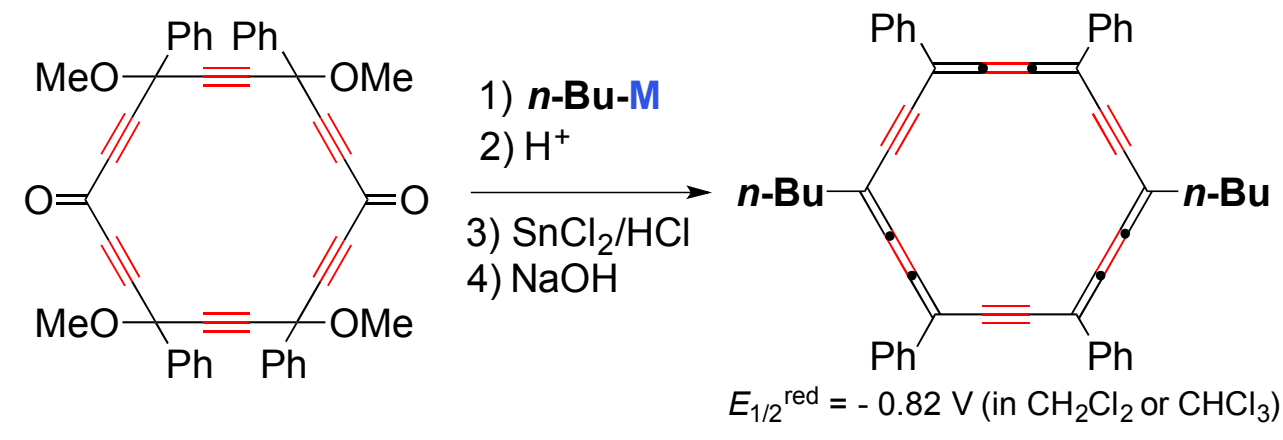

Increasing yield from $32 \%$ to $57 \%$ : $\mathrm{MgBr}<\mathrm{MgCl}<\mathrm{Li}<\mathrm{CeCl}_{2}$ 